or thyroid hormones, or both, in patients who prove to be hypothyroid is also being considered.

\author{
References \\ 1 Dandona, P, et al, in Dialysis, Transplantation and Nephrology, Proceedings \\ of the European Dialysis and Transplant Association, vol 12, ed J F \\ Moorhead, C Mion, and R A Baillod. London, Pitman Medical, 1975.
}

${ }^{2}$ Silverberg, D S, et al, Canadian Medical Assoication fournal, 1973, 109, 282.

${ }^{3}$ Chopra, I J, et al, fournal of Endocrinology, 1975, 41, 1043.

${ }^{4}$ Cuttelod, S, et al, Metabolism, 1974, 23, 101.

5 Gonzalez-Barcena, D, et al, fournal of Clinical Endocrinology Metabolism, 0 $1973,36,117$.

${ }^{6}$ Dandona, $\mathrm{P}$, and El Kabir, D J, in press.

${ }^{7}$ Carter, J N, et al, Lancet, 1974, 4, 971.

(Accepted 11 November 1976)

\title{
Apparent resistance to hypotensive effect of clonidine
}

\author{
L M H WING, J L REID, D S DAVIES, H J DARGIE, C T DOLLERY
}

British Medical fournal, 1977, 1, 136-138

\begin{abstract}
Summary
Clonidine failed to reduce the blood pressures of two patients with essential hypertension. One was given $5.4 \mathrm{mg} /$ day and the other $6 \mathrm{mg} / \mathrm{day}$, and their respective peak plasma clonidine concentrations were $26.2 \mathrm{ng} / \mathrm{ml}$ and $14.4 \mathrm{ng} / \mathrm{ml}$. Several months after the end of clonidine treatment a single oral dose of $0.3 \mathrm{mg}$ of clonidine produced maximum falls in blood pressure of $30 / 22 \mathrm{~mm} \mathrm{Hg}$ and $88 / 41 \mathrm{~mm} \mathrm{Hg}$ with peak plasma clonidine concentrations of $1.4 \mathrm{ng} / \mathrm{ml}$ and $0.9 \mathrm{ng} / \mathrm{ml}$. Resistance to the hypotensive effect of high doses of clonidine may be due to stimulation of peripheral alpha-adrenoceptors causing vasoconstriction, which maintains a raised blood pressure.
\end{abstract}

\section{Introduction}

Clonidine is a hypotensive agent widely used to treat patients with high blood pressure. ${ }^{1}$ The reported range of daily doses for optimum blood pressure control is $0 \cdot 15-4.8 \mathrm{mg} .{ }^{2}$ When used in conjunction with a diuretic, however, the maximum effective dose of clonidine may be considerably lower in many patients. ${ }^{3}$ In some patients small initial doses of clonidine have lowered blood pressure but when the dose has been increased the blood pressure has risen and become refractory to the drug. ${ }^{2} \mathrm{We}$ describe here two hypertensive patients whose blood pressures were apparently resistant to high doses of clonidine and the results of studies of both high and low doses of clonidine.

\section{Case 1}

A 44-year-old man presented with accelerated hypertension in May 1967, when his blood pressure was $200 / 140 \mathrm{~mm} \mathrm{Hg}$. He had electrocardiographic (ECG) evidence of left ventricular hypertrophy but no cardiac enlargement or impairment of cardiac or renal function. He

\footnotetext{
Department of Clinical Pharmacology, Royal Postgraduate Medical School, London W12

L M H WING, MB, FRACP, research fellow (present address: Flinders Medical Centre, Bedford Park, South Australia, Australia 5042)

J L REID, DM, MRCP, senior lecturer in clinical pharmacology

D S DAVIES, PHD, reader in biochemical pharmacology

H J DARGIE, MB, MRCP, senior registrar

C T DOLLERY, MB, FRCP, professor of clinical pharmacology
}

had a family history of hypertension, but further investigation failed 8 to show any primary cause. For two years he was treated with several $₫$ antihypertensive drugs, including guanethidine, methyldopa, guan- $\vec{\omega}$ oxan, reserpine, and bethanidine. Blood pressure control was unsatisfactory, and side effects, particularly impotence, were unacceptable. 을 In March 1969 clonidine $(0.225 \mathrm{mg} /$ day) was introduced. The dose was gradually increased over the next two and a half years to $7.2 \mathrm{mg} / \mathrm{G}$ day in an attempt to obtain adequate blood pressure control. His $\stackrel{c}{s}$ impotence improved but he developed side effects of clonidine, $\supset$ including sedation, dry mouth, and constipation. Control of his blood pressure remained difficult despite the addition of propranolol, $₹$ debrisoquine, and hydrallazine. In October 1975 he was admitted to $\vec{\theta}$ hospital for further assessment of treatment. His blood pressure was $\forall$ $170 / 120 \mathrm{~mm} \mathrm{Hg}$ supine and $122 / 70 \mathrm{~mm} \mathrm{Hg}$ erect, and he was receiving . clonidine $5.4 \mathrm{mg}$, bendrofluazide $10 \mathrm{mg}$, propranolol $960 \mathrm{mg}$, and hydrallazine $600 \mathrm{mg}$ daily. Hydrallazine and propranolol were stopped three days before the first (high-dose) clonidine study. After $\overline{0}$ this study clonidine was withdrawn and blood pressure was controlled over the next eight months with labetalol $3.2 \mathrm{~g}$ and bendrofluazide $\mathbb{D}$ $10 \mathrm{mg}$ daily. This treatment was interrupted 16 hours before the second (low-dose) clonidine study.

\section{Case 2}

A 51-year-old woman had been hypertensive since her first pregnancy in 1959 (aged 34). There was a family history of hypertension, $\dot{\sigma}$ but investigation had shown no primary cause. Antihypertensive treatment was started with rauwolfia alkaloids in 1962, when her blood $\dot{\delta}$ pressure was $190 / 125 \mathrm{~mm} \mathrm{Hg}$. This treatment was continued until 3 1972 , when, with a blood pressure of $210 / 130 \mathrm{~mm} \mathrm{Hg}$, treatment was changed to a thiazide diuretic, debrisoquine, and clonidine, the latter $\underset{\partial}{\supset}$ in an initial daily dose of $0.2 \mathrm{mg}$. Blood pressure control remained $\tilde{N}$ difficult, however, despite the subsequent use of methyldopa, $\rightarrow$ bethanidine, propranolol, and an increased dose of clonidine to a 0 maximum of $6 \mathrm{mg} /$ day by June 1974. She complained of sodation, dry mouth, and constipation on clonidine. In November 1975 she $N$ was admitted to hospital for further changes of treatment. At this time $\mathrm{C}$ blood pressure was $186 / 122 \mathrm{~mm} \mathrm{Hg}$ supine and $173 / 126 \mathrm{~mm} \mathrm{Hg}$ erect, and she was receiving clonidine $6 \mathrm{mg}$, propranolol $480 \mathrm{mg}$, and bendrofluazide $10 \mathrm{mg}$ daily. Propranolol was withdrawn three days before the first clonidine study. After this study clonidine was with- of drawn, and her blood pressure was controlled on labetalol $2.4 \mathrm{~g}$ and bendrofluazide $10 \mathrm{mg}$ daily. Seven months later the second clonidine study was performed 16 hours after the last dose of labetalol.

\section{Method}

Each patient was investigated twice: once during long-term $\frac{0}{0}$ clonidine treatment and again seven to eight months after stopping clonidine. In the first study both patients received their usual morning dose of clonidine $-1.8 \mathrm{mg}$ (case 1) and $1.5 \mathrm{mg}$ (case 2) orally. In the second they were given a single $0 \cdot 3-\mathrm{mg}$ dose of clonidine orally. Both patients gave their informed written consent to the procedures. The investigation was performed in a quiet clinical laboratory, where the 
patients rested supine throughout each study. They had fasted and received no drugs since the previous evening. An intravenous cannula in a forearm vein was used for blood sampling.

Supine blood pressure was recorded with an Arteriosonde 1217 automatic sphygmomanometer before clonidine and at intervals up to nine hours after dosing. Heparinised blood samples $(25 \mathrm{ml})$ were taken at intervals up to 48 hours after drug administration for measuring plasma clonidine concentrations by selected ion-detection gas chromatography and mass spectrometry. ${ }^{5}$

\section{Results}

In case 1 resting supine blood pressure before the first study was $155 / 112 \mathrm{~mm} \mathrm{Hg}$. After oral clonidine $1.8 \mathrm{mg}$ the blood pressure rose to a maximum of $193 / 142 \mathrm{~mm} \mathrm{Hg}$ at three hours and then fell to $176 / 124 \mathrm{~mm} \mathrm{Hg}$ at eight hours. The blood pressure never fell below the pre-dose level. In the second study blood pressure was $164 / 112$ $\mathrm{mm} \mathrm{Hg}$ before dosing and fell to $134 / 90 \mathrm{~mm} \mathrm{Hg}$ three hours after oral clonidine $0.3 \mathrm{mg}$. At nine hours the blood pressure was $178 / 119$ $\mathrm{mm} \mathrm{Hg}$ (fig 1).

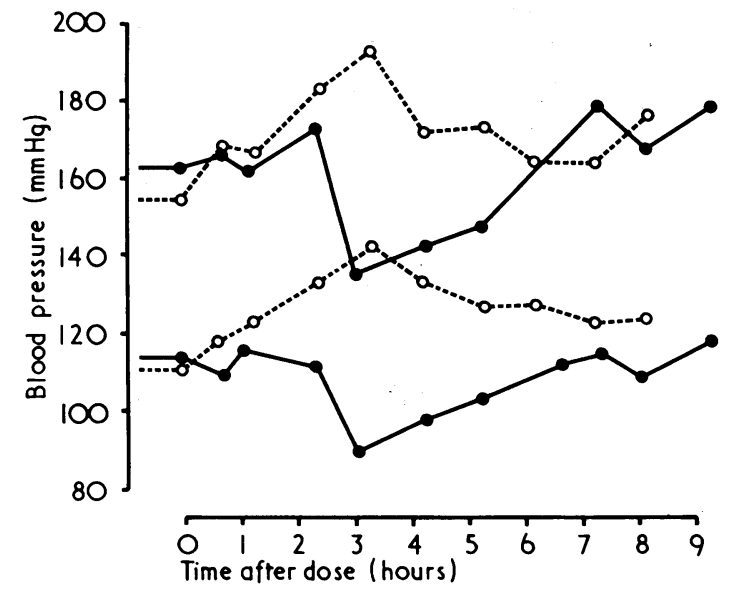

FIG 1-Case 1. Systolic and diastolic blood pressure after oral clonidine $1.5 \mathrm{mg}$ while on long-term high-dose treat$\left(\mathrm{O}-\mathrm{O}_{\text {) }}\right.$ and after $0.3 \mathrm{mg}$ clonidine orally seven months after stopping clonidine (-O).

In case 2 resting supine blood pressure before the first study was $178 / 120 \mathrm{~mm} \mathrm{Hg}$ and did not fall until six hours after an oral dose of $1.5 \mathrm{mg}$ of clonidine. In the second study blood pressure was $200 / 115$ $\mathrm{mm} \mathrm{Hg}$ before dosing, and it fell rapidly to $112 / 74 \mathrm{~mm} \mathrm{Hg}$ at three

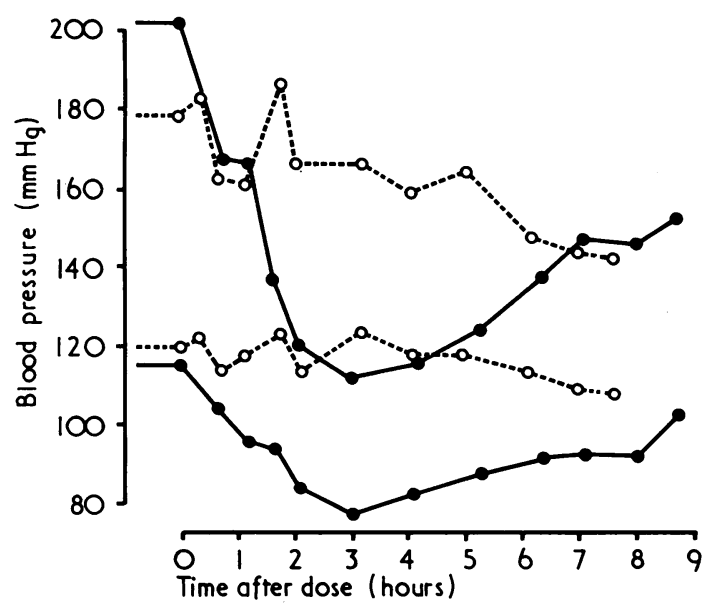

FIG 2-Case 2. Systolic and diastolic blood pressure after oral clonidine $1.8 \mathrm{mg}$ while on long-term high-dose treatment $\left(O-O^{-}\right)$and after $0.3 \mathrm{mg}$ clonidine orally eight months after stopping the drug (-O). hours after clonidine $0.3 \mathrm{mg}$. At nine hours blood pressure was $151 / 104 \mathrm{~mm} \mathrm{Hg}$ (fig 2).

The plasma clonidine concentration before dosing and the peak level on each occasion are shown in the table. During long-term highdose clonidine treatment the peak levels were $26.2 \mathrm{ng} / \mathrm{ml}$ and 14.4 $\mathrm{ng} / \mathrm{ml}$ respectively compared with $1.4 \mathrm{ng} / \mathrm{ml}$ and $0.9 \mathrm{ng} / \mathrm{ml}$ when a single $0.3 \mathrm{mg}$ dose was given several months after stopping clonidine.

Plasma clonidine concentration $(\mathrm{ng} / \mathrm{ml}$ ) in two hypertensive patients before and after clonidine when on chronic high-dose treatment (study 1) and seven to eight months later, after a single oral dose of clonidine $0.3 \mathrm{mg}$ (study 2)

\begin{tabular}{|c|c|c|c|}
\hline & & Predose & Peak \\
\hline $\begin{array}{l}\text { Case } 1 \\
\text { Case } 2\end{array}\left\{\begin{array}{l}\text { Study } 1 \\
\text { Study } 2 \\
\text { Study } 1 \\
\text { Study } 2\end{array}\right.$ & $\begin{array}{ll}\because & . \\
\because & \cdots \\
. & \cdots\end{array}$ & $\begin{array}{l}18 \cdot 0 \\
11 \cdot 3\end{array}$ & $\begin{array}{r}26 \cdot 2 \\
1.4 \\
14.4 \\
0.9\end{array}$ \\
\hline
\end{tabular}

These plasma concentrations were appropriate for the different oral doses, as the total body plasma clearance of clonidine was similar in these patients to values reported in normotensive ${ }^{5}$ and hypertensive subjects. ${ }^{6}$

\section{Discussion}

The two hypertensive patients reported in this paper were both resistant to high doses and high plasma concentrations of clonidine. After clonidine had been withdrawn for seven to eight months the administration of a single $0.3-\mathrm{mg}$ dose produced a substantial fall in blood pressure in both patients (30/22 $\mathrm{mm} \mathrm{Hg}$ in case $1 ; 88 / 41 \mathrm{~mm} \mathrm{Hg}$ in case 2 ). These reductions in pressure are similar to those observed in normotensive and other hypertensive people after a $0 \cdot 3-\mathrm{mg}$ dose. ${ }^{6}$ ?

Resistance to the high doses of clonidine cannot be explained pharmacokinetically because the doses produced appropriately high concentrations of the drug in the patients' plasma. It is unlikely that treatment with labetalol before the second study could have contributed substantially to the hypotensive effect of clonidine. Labetalol has a short plasma half life, ${ }^{8}$ and in both patients the second clonidine administration was performed 16 hours after the last dose of labetalol, when the blood pressure had returned to a high level.

Two pharmacological explanations for the observed resistance to the high dose seem possible: tolerance and peripheral alphareceptor stimulation.

Clonidine is an alpha-adrenoceptor agonist in both the brain and the periphery. ${ }^{10}$ Stimulation of alpha-receptors in the central nervous system causes a reduction in sympathetic outflow and is accompanied by sedation and a fall in salivary flow. ${ }^{13}$ Tolerance to the central side effects of sedation and dry mouth seemed to develop during eight days of treatment, but tolerance to the hypotensive effect was not observed during the same period of time. ${ }^{6}$ In the high-dose study the patients remained awake despite peak plasma concentrations of 26.2 and $14.4 \mathrm{ng} / \mathrm{ml}$, but in the low-dose study the patients were heavily sedated despite peak plasma concentrations of only 1.4 and $0.9 \mathrm{ng} / \mathrm{ml}$. Thus tolerance to the central sedative effects of clonidine did occur, and similar tolerance to the hypotensive effect may also have been present.

The second explanation, which we favour, is that at high concentrations peripheral alpha-receptor stimulation predominated, leading to peripheral vasoconstriction even in the presence of inhibition of central sympathetic outflow. In normotensive $^{5}$ and hypertensive people ${ }^{6}$ the hypotensive effect of clonidine is related to the plasma concentration up to $2 \mathrm{ng} / \mathrm{ml}$, but at higher concentrations the hypotensive effect is reduced. Furthermore, clonidine overdose may be associated with a rise in blood pressure. ${ }^{9}$ The diminishing hypotensive effect of clonidine at plasma concentrations greater than $2 \mathrm{ng} / \mathrm{ml}$ may be 
due to the increasing importance of peripheral alpha-adrenoceptor stimulation once a maximal central effect has been reached. Differences in the sensitivities of central and peripheral alpha-adrenoceptors to clonidine have been reported. ${ }^{11-13}$

Thus the balance of the evidence favours peripheral stimulation as the cause of drug resistance in patients on very high doses of clonidine. Our observations suggest that the use of high doses of clonidine may be associated with diminishing and not increasing hypotensive effects, and this should be borne in mind when the dose is being adjusted.

We thank Miss $P$ Tippett, Miss E Neill, and Mrs J Daniel for technical help and Miss A Davis and Miss B Edinborough, who kindly typed the manuscript.

LMHW is a fellow in clinical sciences of the National Health and Medical Research Council of Australia and is also supported by the Wellcome Trust. JLR is supported by the Wellcome Trust as a senior fellow in clinical science.

\section{References}

${ }^{1}$ Conolly, M E, in Central Action of Drugs in Blood Pressure Regulation, ed D S Davies and J L Reid, p 268. Kent, Pitman Medical, 1975.

${ }^{2}$ Macdougall, A I, et al, British Medical fournal, 1970, 3, 440.

3 Onesti, G, et al, Circulation Research, 1971, 28 and 29, suppl 11, p 11. Conolly, M E, et al, European fournal of Clinical Pharmacology, 1972, 4, 222.

5 Davies, D S, et al, Clinical Pharmacology and Therapeutics, in press.

6 Wing, L M H, et al, European fournal of Clinical Investigation, 1976, 6, 314. C

' Dollery, C T, et al, Clinical Pharmacology and Therapeutics, 1976, 19, 11.

Martin, L E, et al, British fournal of Pharmacology, 1976, 35, 695.

Hunyor, S N, et al, British Medical fournal, 1975, 4, 23.

${ }^{10}$ Kobinger, W, in Central Action of Drugs in Blood Pressure Regulation, ed D S Davies and J L Reid, p 181. Kent, Pitman Medical, 1975.

11 Schmitt, H, Schmitt, M, European fournal of Pharmacology, 1970, 9, 7. 12 Schmitt, H, Schmitt, M, and Fenard, S, European fournal of Pharmacology, 1971, 14, 98.

${ }^{13}$ Struyker, B H, et al, Life Sciences, 1974, 15, 887.

\title{
Thyrotoxicosis: relations between clinical state and biochemical changes during carbimazole treatment
}

\author{
C H MORTIMER, D C ANDERSON， P LIENDO-CH， R FISHER，V CHAN， M SELF， G M BESSER
}

British Medical fournal, 1977, 1, 138-141

\begin{abstract}
Summary
The relation between clinical and biochemical changes in thyrotoxicosis were studied in 12 patients with Graves's disease who were being treated with carbimazole. Clinical assessment (using the Crooks-Wayne index) was combined with the measurement of free thyroxine and triiodothyronine indices (FT4I and FT3I) and the assessment of two tissue markers of thyroid hormone actionsex-hormone-binding globulin (SHBG) levels and the thyrotrophin responses to TRH. In general the FT4I and FT3I fell rapidly once treatment was started, and returned to normal in one to four weeks, followed shortly by SHBG levels. The thyrotrophin response returned at this time in two patients, who still had borderline high levels of FT3I and SHBG. The clinical score fell more slowly and variably and was less closely related to any of the biochemical indices than these were to each other.

During the early phase of treatment with antithyroid drugs the clinical evaluation may be an unreliable indicator of persisting thyroid hormone excess, and when the patient seems clinically but not biochemically thyrotoxic the symptoms should be treated on their own merits with beta-blocking drugs and not with increased doses of antithyroid drugs.
\end{abstract}

Department of Endocrinology, Medical Professorial Unit, and Department of Chemical Pathology, St Bartholomew's Hospital, London EC1A 7BE

C H MORTIMER, MB, MRCP, research lecturer in medicine

D C ANDERSON, MD, MRCP, lecturer in medicine (now senior lecturer in medicine, Manchester Royal Infirmary)

P LIENDO-CH, MB, research fellow

R FISHER, MSC, biochemist

V CHAN, PHD, biochemist (now lecturer, Department of Medicine, Queen Mary Hospital, University of Hong Kong)

M SELF, FIMLT, technician

G M BESSER, MD, FRCP, professor of endocrinology

\section{Introduction}

Despite advances in the treatment of thyrotoxicosis after the introduction of antithyroid drugs some practical problems remain, particularly in gauging the doses required. Antithyroid drugs are directed at reducing thyroid hormone production, which is ultimately responsible for the symptoms and signs of thyrotoxicosis. Many of these clinical features result from secondary changes, however, including increased tissue sensitivity to catecholamines, which may not be rapidly reversed when the thyroid hormone excess is controlled. We examined the relation between clinical evidence of thyrotoxicosis, serum levels of thyroid hormones, and two objective biochemical markers of tissue response to thyroid hormones before and during carbimazole treatment. Our aim was to clarify the relation during treatment between circulating thyroid hormone levels, other objective biochemical changes, and the clinical manifestations of thyrotoxicosis.

\section{Patients and methods}

Five men and seven women aged 25 to 62 years with diffuse goitre and thyrotoxic Graves's disease were studied. After baseline observations were made carbimazole $45 \mathrm{mg} /$ day was given until clinical improvement was seen. Then the dose was reduced gradually on clinical grounds to $5-15 \mathrm{mg} /$ day for at least one year in all but three patients. One of these (case 1) developed a cutaneous rash during the seventh week, necessitating prednisolone treatment. The rash improved, but five weeks later leucopenia developed and treatment was changed to propylthiouracil and potassium iodide, followed by partial thyroidectomy. Another patient (case 2) elected to have a thyroidectomy at four months. One patient (case 3) arbitrarily varied her own dosage over the first 16 weeks so she did not follow a taperingdose regimen. Ten patients were also studied during the period immediately after stopping carbimazole; two of them (cases 4 and 5) suffered a recurrence of thyrotoxicosis.

Clinical status was assessed serially by a single observer with no knowledge of the biochemical changes. It was scored according to the Crooks-Wayne index. ${ }^{1}$ Scores of 6-31 suggest thyrotoxicosis. When the score was 5 or less clinical status was also assessed by the hypothyroid index of Billewicz et al. ${ }^{2}$ Results of this are not presented since no patient became clinically hypothyroid. 